Draw the Lightning Down 
This page intentionally left blank 


\section{Draw the Lightning Down}

Benjamin Franklin and Electrical Technology in the Age of Enlightenment

MICHAEL BRIAN SCHIFFER

With the assistance of

Kacy L. Hollenback and Carrie L. Bell

University of California Press

BERKELEY LOS ANGELES LONDON 
(C) University of California Press

Berkeley and Los Angeles, California

University of California Press, Ltd.

London, England

(C) 2003 by the Regents of the University of California

Library of Congress Cataloging-in-Publication Data

Schiffer, Michael B.

Draw the lightning down : Benjamin Franklin and electrical technology in the age of Enlightenment / Michael Brian Schiffer, with the assistance of Kacy L. Hollenback and Carrie L. Bell.

p. $\quad \mathrm{cm}$.

Includes bibliographical references and index.

ISBN 0-520-23802-8 (alk. paper).

1. Electrical engineering-History-18th century. 2. ElectricityHistory-18th century. 3. Franklin, Benjamin, 1706-1790.

4. Enlightenment. I. Hollenback, Kacy L. II. Bell, Carrie L.

III. Title.

TK16.535 2003

621.3'0973'09033-dc21

2002156533

Manufactured in the United States of America
$\begin{array}{lllllllll}11 & 10 & 09 & 08 & 07 & 06 & 05 & 04 & 03\end{array}$
$\begin{array}{llllllllll}10 & 9 & 8 & 7 & 6 & 5 & 4 & 3 & 2 & 1\end{array}$

The paper used in this publication is both acid-free and totally chlorinefree (TCF). It meets the minimum requirements of ANSI/NISO Z39.481992 (R 1997) (Permanence of Paper). (-) 
For Annette, my loving wife and best friend 
This page intentionally left blank 